\title{
UII AKTIVITAS ANTIFUNGI ANGGUR LAUT (Caulerpa sp.) ASAL PULAU AMBAI SERUI TERHADAP FUNGI Candida krusei DAN Candida albicans
}

\section{ANTIFUNGAL OF SEA GRAPES (Caulerpa sp.) FROM AMBAI SERUI TO Candida krusei AND Candida albicans}

\author{
Kristine Destrianita Siagian ${ }^{1}$, Daniel Lantang ${ }^{2}$, Sepriyanto Dirgantara ${ }^{1}$, \\ Eva Susanty Simaremare ${ }^{1}$ \\ ${ }^{1}$ Program Studi Farmasi, Fakultas MIPA Universitas Cenderawasih, \\ Kampus Uncen Waena, JI Perumnas III Waena Jayapura 99351 Papua, Indonesia \\ ${ }^{2} J u r u s a n$ Biologi, Fakultas MIPA, Universitas Cenderawasih, \\ Kampus Uncen Waena, JI Perumnas III Waena Jayapura 99351 Papua, Indonesia \\ Email: siagiankristine95@gmail.com (Kristine Destrianita Siagian)
}

\begin{abstract}
ABSTRAK
Anggur laut (Caulerpa sp.) memiliki potensi sebagai bahan obat antifungi baru karena mengandung beberapa senyawa aktif seperti saponin dan flavonoid yang bekerja sebagai antifungi. Tujuan dari penelitian ini adalah untuk menguji aktivitas antifungi ekstrak anggur laut (Caulerpa sp.) yang diekstraksi dengan 3 pelarut (dietil eter, etil asetat, dan etanol) terhadap fungi Candida krusei dan Candida albicans. Pengujian antifungi menggunakan metode difusi cakram dengan Rancangan Acak Lengkap (RAL), 7 perlakuan, dan 3 kali pengulangan, dimana 7 perlakuan yang dimaksud adalah dengan menggunakan konsentrasi 100, 250, 500, 750, dan 1000 ppm, kontrol positif menggunakan flukonazol $5 \mu \mathrm{g}$ dan kontrol negatif yaitu akuades steril. Hasil penelitian menunjukkan bahwa ketiga pelarut dari ekstrak dietil eter, etil asetat, dan etanol dari anggur laut mampu menghambat pertumbuhan fungi Candida krusei dan Candida albicans pada konsentrasi 100, 250, 500, 750, dan 1000 ppm. Hasil uji menunjukkan konsentrasi efektif untuk menghambat fungi Candida krusei pada ekstrak etanol dan Candida albicans adalah pada ekstrak etil asetat adalah 1000 ppm.
\end{abstract}

Kata kunci: anggur laut (Caulerpa sp.), antifungi, Candida krusei, Candida albicans.

\section{ABSTRACT}

Sea grapes (Caulerpa sp.) has the potency as a new antifungal agent because it contains several antifungal compounds such as saponins, flavonoids. The purpose of this study was to evaluate the antifungal activity of extract of anggur laut (Caulerpa sp.) The biomass of anggur laut was extracted with 3 solvents (diethyl ether, ethyl acetate, and ethanol) and the extracts were tested against Candida krusei and Candida albicans. Antifungal test was conducted using disc diffusion method. Complete Randomized Design (CRD) with 7 treatments and 3 replications were performed, they were extracts 
with concentration of 100,250,500,750, $1000 \mathrm{ppm}$, positive control using fluconazole 5 $\mu \mathrm{g}$, and negative control using sterile distilled water. The results showed that the three extracts of diethyl ether, ethyl acetate, and ethanol extract of sea grapes were capable of inhibiting the growth of Candida krusei and Candida albicans at concentrations of 100, $250,500,750$, and $1000 \mathrm{ppm}$. It indicated that the effective concentration of ethanol extract to inhibit Candida krusei and ethyl acetate extract to inhibit Candida albicans were 1000 ppm.

Key words: sea grapes (Caulerpa sp.), antifungal, Candida krusei, Candida albicans. 


\section{Pendahuluan}

Posisi geografis Indonesia sangat unik, berada di daerah tropis dalam posisi silang antara dua benua yaitu Asia dan Australia dengan dua samudera yaitu Pasifik dan Hindia sehingga dari kondisi geografis inilah Indonesia memiliki kekayaan alam yang sangat melimpah (Irianto, 2009). Indonesia memiliki sumberdaya hayati yang terdapat di daratan maupun perairan yang sangat melimpah.

Alga yang dalam bahasa masyarakat sehari-hari disebut dengan rumput laut terdiri dari tiga kelas yaitu alga merah (Rhodophyceae), alga coklat (Phaeophyceae), dan alga hijau (Chlorophyceae) (Ferial, 2003). Rumput laut (alga) merupakan sejenis tumbuhan tingkat rendah dan mengandung berbagai komponen yang dapat dimanfaatkan bagi kehidupan manusia dan dapat digunakan sebagai antioksidan dari kandungan pigmen tambahan yaitu karotenoid.

Pemanfaatan obat dari bahan alam cenderung meningkat sejalan dengan meningkatnya efek samping dari obat kimia. Hal inilah yang menyebabkan masyarakat lebih memilih menggunakan obat tradisional (back to nature). Penggunaan obat tradisional dipengaruhi dengan meningkatnya berbagai jenis penyakit salah satunya adalah penyakit infeksi (Permenkes RI, 2013).

Penyakit infeksi merupakan penyakit yang paling banyak terjadi pada masyarakat yang disebabkan oleh mikroba salah satunya oleh fungi. Perkembangan penyakit infeksi di negara tropis seperti Indonesia terutama disebabkan oleh suhu udara yang lembab, serta terkait dengan kesadaran masyarakat terhadap kebersihan dan kesehatan. Kondisi lainnya dipengaruhi oleh beberapa faktor seperti kelembaban, suhu panas, trauma, respons imunitas yang turun, keadaan sosial, dan kurangnya kebersihan (Siregar, 1991).

Hasil penelitian Singkoh (2011) menunjukkan bahwa Caulerpa racemosa memiliki senyawa yang mengandung aktivitas antibakteri pada bakteri Edwardsiela tarda dengan diameter zona hambat sebesar $1,3 \mathrm{~mm}$, bakteri Yersinia enterocolitica dengan diameter zona hambat sebesar 1,4 mm dan bakteri Proteus stuartii dengan diameter zona hambat sebesar 1,3 $\mathrm{mm}$. Menurut penelitian dari Majula dan Rao (2014) menyatakan bahwa ekstrak alga Caulerpa taxifolia memberikan aktivitas 
antibakteri terhadap bakteri gram positif dan negatif dan antifungi dengan menggunakan pelarut kloroform, metanol, n-heksana, dan air terhadap fungi Candida albicans dengan diameter zona hambat $21 \mathrm{~mm}$ dan ekstrak alga Caulerpa racemosa memberikan aktivitas antibakteri terhadap bakteri gram positif dan negatif, dan antifungi terhadap fungi Aspergillus niger dengan diameter zona hambat $22 \mathrm{~mm}$.

Menurut Dimara dan Yenusi (2011) Caulerpa racemosa mampu menghambat pertumbuhan bakteri Staphylococcus aureus pada konsentrasi larutan pigmen $100 \%$ dengan Diameter Daerah Hambatan (DDH) sebesar 2,170 $\mathrm{cm}$, selanjutnya pertumbuhan bakteri Escherichia coli dapat pula dihambat oleh pigmen klorofil Caulerpa racemosa pada konsentrasi larutan pigmen 100\% dengan DDH sebesar 2,100 cm. Ekstrak kasar pigmen klorofil Caulerpa racemosa memiliki nilai $I_{50}$ sebesar 2350,3 ppm dan dapat berfungsi sebagai senyawa penangkal radikal bebas (antioksidan). Tujuan dari penelitian ini adalah untuk menguji aktivitas antifungi ekstrak anggur laut (Caulerpa sp.).

\section{Metode Penelitian}

Alat dan Bahan

Alat yang digunakan dalam penelitian yaitu: alat-alat gelas, blender, cawan petri, mikropipet, autoklaf, jangka sorong, timbangan analitik, pembakar bunsen, magnetik stirer, pinset, kawat ose, inkubator, rotary evaporator, hot plate, vortex, lemari pendingin, dan laminar air flow (LAF). Bahan-bahan yang digunakan pada penelitian ini yaitu sampel anggur laut (Caulerpa sp.), larutan etanol 96\%, akuades, air suling steril, kertas saring, flukonazol (pembanding positif), dan media nutrient agar (NA).

Jalannya Penelitian

1. Pengumpulan sampel

Pengambilan sampel anggur laut dilakukan di Pulau Ambai Serui. Sampel yang didapat diambil kemudian dimasukkan ke dalam kantong plastik selama pengangkutan.

2. Pembuatan simplisia

Pertama-tama sampel Caulerpa sp. yang telah diambil, kemudian disortasi dan dicuci menggunakan air yang mengalir serta dilakukan perendaman selama tiga hari dengan tujuan untuk menghilangkan garamgaram dan kotoran-kotoran seperti lumut dan pasir. Selanjutnya sampel 
ditiriskan kemudian ditimbang dan selanjutnya dikeringkan di bawah sinar matahari. Sampel yang telah kering kemudian ditimbang dan dihaluskan dengan menggunakan blender.

3. Pembuatan ekstrak

Pembuatan ekstrak dilakukan
dengan ekstraksi bertingkat
menggunakan metode maserasi
dengan menggunakan pelarut
etanol, etil asetat, dan dietil eter
masing-masing dengan
perbandingan 2:20 selama $1 \times 24$ jam
selama 3 hari. Ketiga maserat yang
dihasilkan masing-masing pelarut
dipisahkan dari pelarutnya dengan
cara diuapkan menggunakan rotary
evaporator sehingga diperoleh
ekstrak pekat. Rendemen yang
diperoleh kemudian ditimbang dan
dicatat.

4. Uji aktivitas antifungi

Konsentrasi ekstrak yang digunakan dalam pengujian adalah 1000, 750, 500, 250, dan 100 ppm. Pengujian aktivitas antifungi dari ekstrak anggur laut terhadap Candida albicans dan Candida krusei dilakukan dengan menggunakan metode difusi cakram. Pada metode ini dilihat daerah bening yang dihasilkan di sekitar cakram. Media agar yang masih cair dituangkan dalam cawan petri steril, kemudian dibiarkan memadat pada suhu kamar. Setelah memadat, suspensi yang telah dibuat, diratakan pada permukaan media agar dengan menggunakan batang $\mathrm{L}$ secara merata. Setelah itu diletakkan kertas cakram steril yang telah direndam ke dalam semua larutan ekstrak uji (ekstrak dietil eter, etil asetat, dan etanol) dengan masing-masing konsentrasi ekstrak pada media agar yang telah diberi fungi. Kontrol negatif yang digunakan adalah akuades steril dan kontrol positifnya yaitu flukonazol $5 \mu \mathrm{g}$. Setelah itu, kertas cakram didiamkan beberapa saat agar menyerap larutan uji, kemudian diletakkan pada permukaan agar dengan menggunakan pinset steril. Selanjutnya sampel diinkubasikan pada suhu $37{ }^{\circ} \mathrm{C}$ selama 3 hari. Setelah di-inkubasi, sampel diamati dan diukur diameter zona hambat yang terbentuk berupa daerah bening di sekitar cakram dalam satuan (mm) menggunakan jangka sorong.

5. Analisis data 
Data hasil pengujian aktivitas anggur laut terhadap diameter zona hambat pertumbuhan fungi dianalisis dengan metode RAL dengan 7 perlakuan dan 3 kali pengulangan. Tujuh perlakuan yang dimaksud adalah menggunakan konsentrasi 1000, 750, 500, 250, dan 100 ppm, kontrol positif (flukonazol), dan kontrol negatif yaitu akuades steril. Jika analisis varians (ANOVA) menunjukkan konsentrasi perlakuan yang diteliti berbeda nyata maka dilakukan uji lanjut dengan menggunakan uji BNJ (Beda Nyata Jujur).

\section{Hasil dan Pembahasan}

Pembuatan Ekstrak

Pembuatan ekstrak anggur laut dilakukan dengan ekstraksi cara dingin yaitu maserasi bertingkat menggunakan pelarut dietil eter, etil asetat, dan etanol. Metode maserasi dilakukan karena pengerjaannya cukup sederhana dan untuk menghindari rusaknya zat aktif yang terkandung dalam sampel. Proses ekstraksi bertingkat bertujuan untuk memisahkan senyawa berdasarkan tingkat kepolaran pelarut. Maserasi bertingkat dilakukan dengan mengekstraksi sampel anggur laut (Caulerpa sp.) dengan pelarut berbeda secara berurutan yang dimulai dengan pelarut nonpolar (dietil eter), semipolar (etil asetat) kemudian polar (etanol) sehingga diperoleh ekstrak yang mengandung senyawa nonpolar, semipolar, dan polar. Hasil pembuatan ekstrak anggur laut dengan tingkat kepolaran pelarut yang berbeda-beda diperoleh hasil pada Tabel 1.

Tabel 1. Hasil pembuatan ekstrak

\begin{tabular}{ccc}
\hline Pelarut & Berat Ekstrak (gram) & Rendemen (\%) \\
\hline Dietil Eter & 1,25 & 0,62 \\
Etil Asetat & 2,94 & 1,47 \\
Etanol & 4,91 & 2,45 \\
\hline
\end{tabular}

\footnotetext{
Hasil penapisan fitokimia sangat bervariasi dan hal ini dipengaruhi anggur laut tertera pada Tabel 2 . oleh faktor musim, lokasi geografis Kandungan kimia rumput laut tersebut tempat tumbuh, jenis spesies, umur
} 
panen, dan kondisi lingkungan. Selain itu, perbedaan kandungan kimia sangat tergantung pada jenis, kondisi tempat tumbuh, dan masa perkembangan (Maharani dan Rizki, 2013).

Tabel 2. Hasil penapisan fitokimia simplisia dan ekstrak

\begin{tabular}{ccccc}
\hline \multirow{2}{*}{ Golongan Senyawa } & \multicolumn{4}{c}{ Hasil } \\
\cline { 2 - 5 } & Simplisia & Dietil Eter & Etil Asetat & Etanol \\
\hline Alkaloid & - & - & - & - \\
Flavonoid & + & - & + & + \\
Saponin & + & + & - & + \\
Tanin & - & - & - & - \\
Kuinon & - & - & & - \\
\hline
\end{tabular}

Uji Aktivitas Antifungi

Uji aktivitas antifungi ini dilakukan dengan menggunakan metode difusi cakram. Hasil diameter rata-rata pengukuran zona hambat ekstrak terhadap fungi Candida krusei dan Candida albicans dapat dilihat pada Tabel 3 dan Tabel 4. Data uji BNJ menunjukkan bahwa aktivitas antifungi berbeda nyata terhadap Candida krusei dan Candida albicans (Tabel 5-7). Berdasarkan kriteria daya hambat menurut Davis dan Stout (1971), dari kriteria kekuatan daya hambat antifungi ekstrak dietil eter, etil asetat dan etanol 96\% dari anggur laut (Caulerpa sp.) pada konsentrasi 100, 250, 500, 750, dan 1000 ppm terhadap fungi Candida krusei dan Candida albicans dikategorikan kekuatan daya hambat sedang.

Adanya aktivitas antifungi yang dihasilkan anggur laut diduga disebabkan dari senyawa metabolit sekunder yang terkandung dalam ekstrak etanol dan etil asetat dari anggur laut yaitu senyawa flavonoid dan saponin. Sedangkan pada ekstrak dietil eter dari anggur laut hanya terkandung senyawa saponin, hal ini berkaitan dengan sifat kepolaran eter yang bersifat nonpolar sehingga hanya sedikit komponen senyawa aktif yang larut di dalamnya. 
Tabel 3. Hasil zona hambat terhadap fungi Candida krusei

\begin{tabular}{cccc}
\hline \multirow{2}{*}{$\begin{array}{c}\text { Konsentrasi } \\
(\mathbf{p p m})\end{array}$} & \multicolumn{3}{c}{ Diameter Rata-rata Zona Hambat Ekstrak $(\mathbf{m m})$} \\
\cline { 2 - 4 } & Dietil Eter & Etil Asetat & Etanol \\
\hline K (-) & 0,00 & 0,00 & 0,00 \\
100 & 7,28 & 6,76 & 8,01 \\
250 & 7,32 & 7,53 & 8,12 \\
500 & 7,50 & 7,52 & 8,25 \\
750 & 7,54 & 7,64 & 9,22 \\
1000 & 7,81 & 8,50 & 9,44 \\
K (+) & 29,77 & 28,02 & 28,59 \\
\hline
\end{tabular}

Tabel 4. Hasil zona hambat terhadap fungi Candida albicans

\begin{tabular}{cccc}
\hline \multirow{2}{*}{$\begin{array}{c}\text { Konsentrasi } \\
\text { (ppm) }\end{array}$} & \multicolumn{3}{c}{ Diameter Rata-rata Zona Hambat Ekstrak (mm) } \\
\cline { 2 - 4 } Dietil Eter & Etil Asetat & Etanol \\
\hline K (-) & 0,00 & 0,00 & 0,00 \\
100 & 6,75 & 7,79 & 7,51 \\
250 & 7,14 & 8,55 & 7,81 \\
500 & 7,38 & 8,57 & 7,89 \\
750 & 7,68 & 8,70 & 8,51 \\
1000 & 8,10 & 9,11 & 8,55 \\
K (+) & 32,59 & 32,12 & 29,32 \\
\hline
\end{tabular}

Tabel 5. Analisis uji BNJ ekstrak dietil eter (Caulerpa sp.)

\begin{tabular}{ccc}
\hline \multirow{2}{*}{$\begin{array}{c}\text { Konsentrasi } \\
(\mathbf{p p m})\end{array}$} & \multicolumn{2}{c}{ Rerata $(\mathbf{m m})$} \\
\cline { 2 - 3 } $\mathrm{K}(-)$ & Candida krusei & Candida albicans \\
100 & 0,00 & 0,00 \\
250 & 7,28 & 6,79 \\
500 & 7,32 & 7,14 \\
750 & 7,50 & 7,38 \\
1000 & 7,54 & 7,68 \\
$\mathrm{~K}(+)$ & 7,81 & 8,10 \\
& 28,71 & 31,34 \\
& BNJ $\alpha 0,05$ & BNJ $\alpha 0,05$ \\
& 1,038079971 & 1,877557 \\
\hline
\end{tabular}


Tabel 6. Analisis uji BNJ estrak etil asetat (Caulerpa sp.)

\begin{tabular}{ccc}
\hline \multirow{2}{*}{$\begin{array}{c}\text { Konsentrasi } \\
\text { (ppm) }\end{array}$} & \multicolumn{2}{c}{ Rerata $(\mathbf{m m})$} \\
\cline { 2 - 3 } K(-) & Candida krusei & Candida albicans \\
100 & 0,00 & 0,00 \\
250 & 6,76 & 7,79 \\
500 & 7,35 & 8,55 \\
750 & 7,52 & 8,57 \\
1000 & 7,64 & 8,70 \\
$\mathrm{~K}(+)$ & 8,50 & 9,11 \\
& 28,71 & 31,34 \\
& BNJ $\alpha 0,05$ & BNJ $\alpha 0,05$ \\
& 1,059 & 2,004 \\
\hline
\end{tabular}

Tabel 7. Analisis uji BNJ ekstrak etanol (Caulerpa sp.)

\begin{tabular}{cccc}
\hline $\begin{array}{c}\text { Konsentrasi } \\
(\mathbf{p p m})\end{array}$ & $\begin{array}{c}\text { Rerata }(\mathbf{m m}) \\
(\text { C. } \text { krusei) }\end{array}$ & Notasi & $\begin{array}{c}\text { Rerata }(\mathbf{m m}) \\
\text { (C.albicans) }\end{array}$ \\
\hline $\mathrm{K}(-)$ & 0,00 & $\mathrm{a}$ & 0,00 \\
100 & 8,01 & $\mathrm{~b}$ & 7,57 \\
250 & 8,12 & $\mathrm{~b}, \mathrm{c}$ & 7,81 \\
500 & 8,25 & $\mathrm{~b}, \mathrm{c}$ & 7,89 \\
750 & 9,22 & $\mathrm{c}, \mathrm{d}$ & 8,51 \\
1000 & 9,44 & $\mathrm{~d}$ & 8,55 \\
$\mathrm{~K}(+)$ & 28,71 & $\mathrm{e}$ & 31,34 \\
& BNJ $\alpha 0,05$ & & BNJ $\alpha 0,05$ \\
& 1,077 & & 1,874 \\
\hline
\end{tabular}

\begin{abstract}
Mekanisme penghambatan saponin terjadi melalui gangguan permeabilitas membran sel sehingga menyebabkan sel lisis maka keluarlah berbagai komponen penting dari dalam sel mikroba yaitu protein, asam nukleat, nukleotida, dan lain-lain sehingga mengakibatkan kematian mikroba (Ariani dkk., 2013). Senyawa flavonoid memiliki kemampuan membentuk ikatan dengan protein dan dinding sel
\end{abstract}

mikroba. Flavonoid yang merupakan turunan fenol dapat berinteraksi dengan sel mikroba sehingga terbentuk kompleks fenolprotein diikuti penetrasi fenol ke dalam sel yang menyebabkan koagulasi protein sehingga membran mengalami lisis. Adanya aktivitas antifungi pada ekstrak eter tersebut disebabkan kerja dari senyawa metabolit sekunder berupa saponin yang bekerja sebagai antimikroba dan 
menyebabkan hemolisis pada sel (Harborne, 1987).

\section{Kesimpulan}

Ekstrak anggur laut (Caulerpa sp.) mempunyai aktivitas antifungi terhadap fungi Candida krusei dan Candida albicans terhadap pelarut dietil eter, etil asetat, dan etanol. Ekstrak yang paling efektif dalam menghambat pertumbuhan fungi Candida krusei adalah pelarut etanol, dan untuk fungi Candida albicans adalah pelarut etil asetat pada konsentrasi 1000 ppm.

\section{Daftar Pustaka}

Ariani, A., Hartati, S., dan Yohanes, M. 2013. Pemanfaatan saponin daun akasia (Acacia auriculiformis $\mathrm{A}$. Cunn) sebagai pembusa alami dan agensia atibakteri dalam sabun cair. Prosiding Seminar Nasional Penelitian, Pendidikan, dan Penerapan MIPA, 18 Mei 2013, FMIPA, Universitas Negeri Yogyakarta.

Davis, W., Stout, T. 1971. Disc PITE methods of microbiological antibiotic assay. Microbiology, 2(4):659-665.

Dimara, L. dan Yenusi, T.N.B. 2011. Uji aktivitas antibakteri dan antioksidan ekstrak pigmen klorofil rumput laut Caulerpa racemosa (Forsskal) J. Agardh. Jurnal Biologi Papua, 3(2):53-58.
Ferial, E.W. 2003. Pengenalan dan Teknik Identifikasi Makroalgae. Makasar: Fakultas Matematika Dan Ilmu Pengetahuan Alam Universitas Hasanuddin.

Harborne, J.B. 1987. Metode Fitokimia Penuntun Cara Modern Menganalisis Tumbuhan. Bandung: Penerbit ITB.

Irianto, K. 2009. Ekologi Laut Indonesia. Bandung: Sarana Ilmu Pustaka.

Maharani, A.M. dan Rizki, W. 2013. Pembuatan alginat dari rumput laut untuk menghasilkam produk dengan rendemen dan viskositas tinggi. http://eprints.undip.ac.id/3753/ Data diakses pada 5 Januari 2018.

Majula, E. dan Rao, G.M.N. 2014. In vitro study of antimicrobial activity in marine algae Caulerpa Taxifolia and Caulerpa Racemosa. International Journal of Applied Biology and Pharmaceutical Technology, 5(2):57-62.

Permenkes. 2013. Rencana Induk Pengembangan Bahan Baku Obat Tradisional. Jakarta: Departemen Kesehatan RI.

Singkoh, M.F.O, 2011. Aktivitas antibakteri ekstrak alga laut Caulerpa racemosa dari perairan Pulau Nain. Jurnal Perikanan dan Kelautan Tropis, 6(3):123-127.

Siregar, R.S. 1991. Penyakit Jamur Kulit. Edisi 2. Jakarta: Penerbit Buku Kedokteran EGC. 